$\begin{array}{ll}\text { Türkiye Tarımsal Araştırmalar Dergisi } & \begin{array}{l}\text { Turk J Agric Res } \\ \text { http://dergi.sirt.edu.tr }\end{array} \\ \text { (2015) 2: 1-7 } \\ \text { TÜTAD } \\ \text { ISSN: 2148-2306 }\end{array}$

\title{
Diyarbakır İli Silvan İlçesi Taban Meralarının Vejetasyon Yapısı Üzerinde Bir Araştırma
}

\author{
Seyithan SEYDOŞOĞLU ${ }^{1 *}$, Veysel SARUHAN ${ }^{2}$, Ali MERMER $^{3}$ \\ ${ }^{1}$ GAP Uluslar Arası Tarımsal Araştırma ve Eğitim Merkezi Müdürlüğü, Diyarbakır, TÜRKIYYE \\ ${ }^{2}$ Dicle Üniversitesi, Ziraat Fakültesi, Tarla Bitkileri Bölümü, Diyarbakır, TÜRKIYE \\ ${ }^{3}$ Tarla Bitkileri Merkez Araştırma Enstitüsü Müdürlüğü, Coğrafi Bilgi Sistemleri ve Uzaktan Algılama Bölümü, Ankara, TÜRKIIYE
}

Geliş Tarihi/Received: 02.12 .2014

Kabul Tarihi/Accepted: 10.02 .2015

*Sorumlu Yazar/Correspondence: ege_university47@hotmail.com

Özet: Bu araștırma, Diyarbakır ili Silvan ilçesinin taban kesimindeki 6 farklı merada, vejetasyon yapısının belirlenmesi amacıyla 2014 yılında yürütülmüştür. Araştırmada, her merada toplam 4 lup hattındaki 400 noktada ölçüm yapılarak meradaki bitkilerin türleri, cins ve familyaları, etkileri (azalıcı, çoğalıcı, istilacı), ömür uzunlukları, meraların bitki ile kaplı alan oranları ve türlerin botanik kompozisyondaki oranları saptanmıştır. Yapılan vejetasyon etütlerinde, 11 familyadan, 35 cinse ait toplam 43 türe rastlanmıştır. Merada bitki ile kaplılık oranlarının \% 46.2-72.0, botanik kompozisyondaki buğdaygillerin oranının \% 30.81-72.92, baklagillerin oranının \% 16.89-48.25, diğer familya bitkilerinin oranının ise \% 10.19-39.74 arasında değiştiği tespit edilmiştir. Araştırma sonuçlarına dayanılarak, incelenen meraların vejetasyonlarında genellikle istilacı türlerin baskın olduğu ve bu nedenle de meraların zayıf meralar olduğu, meraların sslah edilmesi için uygun ıslah yöntemlerinin saptanması amacıyla araştırmalar yürütülmesi gerektiği sonucuna varılmıştır.

Anahtar Kelimeler: Mera, botanik kompozisyon, lup metodu, vejetasyon etüdü

\section{Research on the Vegetation Structure of the Pastures in Silvan District, Diyarbakır}

\begin{abstract}
This research was conducted to determine the vegetation structures of the native pastures in the six villages of district Silvan, Diyarbakır, in the year of 2014 .Vegetations of the pastures were studied by the Loop Method. In each pasture 400 loop measurements in 4 lines were made. Plant-covered area rate, botanical composition in the plant covered area was calculated from the loop measurements. 43 plant species of 35 genus from 11 families were determined on the vegetation of the pastures. Plant cover percentages varied between $46.2 \%$ to $72.0 \%$ and botanical composition rate of grasses, legumes and other family plants in the total plant cover varied between $30.81 \%$, and $72.92 \%, 16.89 \%$, and $48.25 \%$, $10.19 \%$, and $39.74 \%$, respectively, as depending on the pastures. From the results of the research, it was concluded that vegetations of the pastures were generally composed of invader plants. Therefore the pastures have poor condition. The research on the determination of proper improvement methods for the pastures must be conducted.
\end{abstract}

Keywords: Pasture, botanical composition, loop method, vegetation survey

\section{Giriș}

Yeryüzünün büyük bir bölümünü çayır ve mera alanları oluşturmaktadır. Bu geniş alanlar dünya nüfusunun beslenmesinin en önemli kaynağı olan hayvansal ürünlerin elde edilmesinde yeri doldurulamayacak, eşsiz kaynaklardır. $\mathrm{Bu}$ potansiyelin değerlendirilmesiyle hayvansal ürünlerin maliyeti azalacak, dünya nüfusu yeterli ve dengeli beslenme imkânına kavuşacaktır. Hayvansal üretimde, kaliteli kaba yem en önemli girdiyi oluşturmaktadır. Karlı ve verimli bir 
hayvansal üretim, kalite ve kantite açısından yeterli kaba yemin ucuza temin edilmesiyle mümkündür. Çayır ve meralar, hayvanların ihtiyaç duyduğu kaba yemin sağlandığı kaynakların en başında gelen yem kaynaklarıdır (Aydın ve Uzun, 2002). Çayır ve mera alanları, sürdürülebilir bir hayvansal üretim sağlamasının yanında; toprağı yerinde tutarak, rüzgâr ve su erozyonunu önlemek suretiyle yaşanabilir ve sürdürülebilir bir çevrenin korunmasının da en önemli unsurudur.

Ülkemiz topraklarının \% 18.7'sini oluşturan meralar (Anonim, 2015), uygun olmayan kullanımlar sonucunda büyük çoğunluğu bitki örtülerini kaybetmiş, verim güçleri ve ot kaliteleri düşmüştür (Gökkuş, 1991). Ülkemiz doğal meralarının bugün içinde bulunduğu durum hayvancılığımızı, dolayısıyla ülke ekonomisini olumsuz yönde etkilediği gibi, toprak ve su kaynaklarının da tahrip olmasına yol açmaktadır. Belirtilen bu sorunların çözülebilmesi için kötü durumdaki meralarımızın vakit geçirilmeden sslah edilerek yeniden bol ve kaliteli yem üretir duruma getirilmeleri gerekmektedir. Ancak, 1slah işleminde başarının ilk şartını, ıslah edilecek alanların çok iyi tanınması oluşturur. Bunun için de ülkemizde değişik ekolojik bölgelerde bulunan meraların özelliklerinin çok iyi bilinmesi gerekir.

Bugüne kadar ülkemizin değişik ekolojik bölgelerinde sürdürülen mera araştırmalarında, bulundukları bölgelere göre değișmek üzere meralarda bitki ile kaplı alan oranının \% 14.0-95.9 arasında değiştiği, meralarımızın verimlerini oluşturan bitkilerin çoğunluğunu hayvanların yararlanamadığı, dikenli türler, çalılar ve yabancı otların oluşturduğu (Erkun, 1971, 1972; Özmen, 1977; Y1lmaz, 1977; Tükel, 1981; Gökkuş, 1984; Çınar, 2001; Uslu, 2005; Şen, 2010; İnal ve ark., 2011) bildirilmektedir.

$\mathrm{Bu}$ çalışma ile Diyarbakır ili meralarının bazı vejetasyon özelliklerinin belirlenerek, gerek islah çalışmaları, gerekse hayvan baskısı ve iklim gibi faktörlerin etkisiyle zaman içinde mera vejetasyonunda meydana gelebilecek değişimlerin izlenmesine olanak sağlayacak bir alt yapının oluşturulması hedeflenmiştir.

\section{Materyal ve Yöntem}

Araştırmada vejetasyon etütleri, Diyarbakır ili Silvan ilçesine bağlı Alabal, Alibey, Darköprü, Dutveren, Eskiocak ve Çatakköprü köylerine ait 6 farklı taban merada, 15 Nisan-15 Haziran 2014 tarihleri arasında yürütülmüştür. İncelenen meralara ait bazı bilgiler Tablo 1'de verilmiş olup; meralar, kuraklık indeksi, bak1 ve rakım bakımından nispeten aynı homojen alanda yer almaktadır (Avă̆ ve ark., 2012).

Diyarbakır ili meralarının botanik kompozisyonunu belirlemek için Modifiye Edilmiş Tekerlekli Lup (halka) Metodu kullanılarak (Koç ve Çakal, 2004), 56 durakta vejetasyon etüdü yapılmıştır. Vejetasyon etüdü meradaki hâkim bitkilerin çiçeklendiği dönemde, her durakta 4 hatta, toplam 400 noktada; doğu, bat1, kuzey ve güney yöneyleri esas alınarak, bitki okunmak suretiyle yapılmıştır.

Okunan her bir bitki türüne ait değerler toplam bitki sayısına oranlanarak türlerin botanik kompozisyondaki oranları tespit edilmiştir. Mera kesimlerinde, bitki örtüsünün toprağı kaplama oranı vejetasyon etüdü sırasında bitkiye rastlanan nokta sayısının ölçülen toplam nokta sayısına oranlanması ile belirlenmiştir. İncelenen meralarla ilgili olarak; bitki ile kaplı alan oranı (\%) ve alana göre botanik kompozisyon oranı (\%), Gökkuş ve ark. (2000) tarafindan açıklanan yöntemlere göre saptanmıştır.

Vejetasyon etütlerinde rastlanan bitkilerin teşhisleri, Edgecombe (1964), Garms ve ark. (1968), Davis (1969), Polunin ve Huxley (1974), Huxley ve Taylor (1977), Weymer (1981), Demiri (1983), Öztan ve Okatan (1985)'nın eserlerinden yararlanılarak yapılmıştır. Türlerin ömür uzunlukları, familyaları ve etkilerinin belirlenmesi Anonim (2008)'e göre yapılmıştır.

Araştırmadan elde edilen veriler; tesadüf blokları deneme desenine göre varyans analizine tabi tutulmuş, bitki ile kaplı alan ve botanik kompozisyon verilerine varyans analizi yapılmadan önce açı transformasyonu uygulanmıştır (Yurtsever, 1984).

Tablo 1. İncelenen mera alanlarına ait bazı coğrafi bilgiler

\begin{tabular}{lcccll}
\hline Köy adı & Alan (da) & Rakım $(\mathrm{m})$ & Enlem & Boylam & Eğim \\
\hline Alabal & 1254 & 665 & 37658850 & 4222012 & Hafif eğimli (\% 2-5) \\
Alibey & 850 & 757 & 37661039 & 4220950 & Hafif eğimli (\% 2-5) \\
Darköprü & 504 & 746 & 37658850 & 4222012 & Hafif eğimli (\% 2-5) \\
Dutveren & 254 & 754 & 37687861 & 4221218 & Hemen hemen düz (\% 0-1) \\
Eskiocak & 100 & 869 & 37685130 & 4221234 & Hemen hemen düz (\% 0-1) \\
Çatakköprü & 1217 & 546 & 37644237 & 4190689 & Hemen hemen düz (\% 0-1) \\
\hline
\end{tabular}




\section{Bulgular ve Tartışma}

Araştırmada incelenen Diyarbakır ili Silvan ilçesine bağlı 6 köy merasında tespit edilen türler, bu türlere ait familyalar, türlerin ömür uzunlukları, etkileri ve botanik kompozisyondaki oranları Tablo 2'de verilmiştir.

Etüt yapılan meralardan Alabal köyü merasında 6 buğdaygil, 2 baklagil, 3 diğer familya türlerinden olmak üzere toplam 11 bitki türü tespit edilmiş, tespit edilen bitki türlerinin 6 adedinin tek yıllık, 5'inin ise çok yıllık; 1'inin azalıcı, 2'sinin çoğalıcı, 8'inin ise istilacı türlerden oluştuğu belirlenmiştir. Alibey köyü merasında 2 buğdaygil, 1 baklagil, 5 diğer familya türlerinden olmak üzere toplam 8 bitki türüne rastlanmıştır. Türlerin 7'sinin tek y1llık, 1'inin iki yıllık, türlerin tamamının De Vries ve ark. (1951)'na göre istilac1 tür olduğu tespit edilmiştir (Tablo 2).

Darköprü köyü merasında 3 buğdaygil, 3 baklagil, 2 diğer familya türlerinden olmak üzere toplam 8 bitki türünün saptandığı, tespit edilen türlerin tamamının tek yıllık ve istilacı türlerden oluştukları belirlenmiştir. Dutveren köyü

Tablo 2. İncelenen meralarda tespit edilen türlerin ömür uzunlukları, familyaları, etkileri ve botanik kompozisyondaki oranı

\begin{tabular}{|c|c|c|c|c|}
\hline Tür & Familya & Ömrü & Etki* & $\begin{array}{c}\text { Botanik } \\
\text { kompozisyondaki } \\
\text { oranı }(\%)\end{array}$ \\
\hline \multicolumn{5}{|c|}{ Alabal } \\
\hline Aegilops neglecta & Poaceae & Tek Yillik & İstilacı & 46.1 \\
\hline Avena sterilis & Poaceae & Tek Y1llik & İstilacı & 2.9 \\
\hline Bromus rubens & Poaceae & Tek Yillık & İstilacı & 5.5 \\
\hline Echinaria capitata & Poaceae & Tek Y1llık & İstilacı & 1.9 \\
\hline Onobrychis caput-galli & Fabaceae & Tek Yillık & İstilacı & 5.5 \\
\hline Onobrychis galegifolia & Fabaceae & Çok Yillik & Azalıcı & 3.9 \\
\hline Phlomis bruguieri & Lamiaceae & Çok Yillık & İstilacı & 5.5 \\
\hline Salvia multicaulis & Lamiaceae & Çok Yillık & İstilacı & 2.9 \\
\hline Stipa arabica & Poaceae & Çok Yillık & Çoğalıcı & 4.2 \\
\hline Teucrium polium & Lamiaceae & Çok Yillık & Çoğalıcı & 1.3 \\
\hline Trachynia distachya & Poaceae & Tek Yillık & Ístilacı & 20.3 \\
\hline \multicolumn{5}{|c|}{ Alibey } \\
\hline Aegilops triuncialis & Poaceae & Tek Yillik & İstilacı & 43.4 \\
\hline Centaurea rigida & Asteraceae & İki Y1llık & İstilacı & 5.5 \\
\hline Crepis sancta & Asteraceae & Tek Yillık & İstilacı & 13.7 \\
\hline Onobrychis caput-galli & Fabaceae & Tek Y1llik & İstilacı & 20.7 \\
\hline Plantago cretica & Plantaginaceae & Tek Yillik & İstilacı & 7.4 \\
\hline Filago eriocephala & Asteraceae & Tek Yillık & İstilacı & 2.7 \\
\hline Scabiosa calocephala & Dipsacaceae & Tek Yillik & İstilacı & 2.3 \\
\hline Rostraria cristata & Poaceae & Tek Y1llık & İstilac1 & 4.3 \\
\hline \multicolumn{5}{|c|}{ Darköprü } \\
\hline Aegilops triuncialis & Poaceae & Tek Yillık & İstilac1 & 20.1 \\
\hline Crepis sancta & Asteraceae & Tek Yillık & İstilacı & 8.1 \\
\hline Hymenocarpus circinnatus & Fabaceae & Tek Yillık & İstilacı & 10.6 \\
\hline Onobrychis caput-galli & Fabaceae & Tek Yillık & İstilacı & 36.1 \\
\hline Rostraria cristata & Poaceae & Tek Yillık & İstilacı & 6.7 \\
\hline Filago eriocephala & Asteraceae & Tek Y1llik & İstilacı & 3.4 \\
\hline Trifolium globosum & Fabaceae & Tek Y1llık & İstilac1 & 8.7 \\
\hline Echinaria capitata & Poaceae & Tek Y1llik & İstilacı & 6.3 \\
\hline \multicolumn{5}{|c|}{ Dutveren } \\
\hline Aegilops triuncialis & Poaceae & Tek Yillık & İstilacı & 2.5 \\
\hline Avena sterilis & Poaceae & Tek Yillık & İstilacı & 30.8 \\
\hline Bromus danthoniae & Poaceae & Tek Y1llik & İstilacı & 7.9 \\
\hline Cynodon dactylon & Poaceae & Çok Yillık & Çoğalıcı & 5.7 \\
\hline Eryngium campestre & Umbelliferae & Çok Yillık & İstilacı & 20.8 \\
\hline Lolium rigidum & Poaceae & Tek Y1llık & İstilacı & 4.3 \\
\hline Onobrychis caput-galli & Fabaceae & Tek Y1llik & İstilacı & 12.5 \\
\hline Picnomon acarna & Asteraceae & Tek Y1llik & İstilacı & 5.0 \\
\hline Plantago cretica & Plantaginaceae & Tek Yillık & İstilacı & 2.2 \\
\hline Picris pauciflora & Asteraceae & Tek Y1llik & İstilacı & 3.6 \\
\hline Rostraria cristata & Poaceae & Tek Yillık & İstilacı & 4.7 \\
\hline
\end{tabular}

*: Azalıcı, çoğalıcı ve istilacı türler De Vries ve ark. (1951)'na göre belirlenmiştir. 
Tablo 2. (devami)

\begin{tabular}{|c|c|c|c|c|}
\hline Tür & Familya & Ömrü & Etki* & $\begin{array}{c}\text { Botanik } \\
\text { kompozisyondaki } \\
\text { oran1 (\%) }\end{array}$ \\
\hline \multicolumn{5}{|c|}{ Eskiocak } \\
\hline Aegilops neglecta & Poaceae & Tek Yillik & İstilacı & 38.1 \\
\hline Aegilops triuncialis & Poaceae & Tek Yill1k & İstilacı & 5.4 \\
\hline Avena sterilis & Poaceae & Tek Yillık & İstilacı & 18.7 \\
\hline Bromus lanceolatus & Poaceae & Tek Yıllık & İstilacı & 10.7 \\
\hline Bromus tectorum & Poaceae & Tek Y1ll1k & İstilacı & 1.8 \\
\hline Coronilla scorpioides & Fabaceae & Tek Yillık & Çoğalıcı & 2.4 \\
\hline Hordeum bulbosum & Poaceae & Çok Y1llık & Çoğalıcı & 7.1 \\
\hline Hordeum spontaneum & Poaceae & Tek Yillik & İstilacı & 3.6 \\
\hline Notobasis syriaca & Asteraceae & Tek Yillik & İstilacı & 0.6 \\
\hline Onobrychis crista-galli & Fabaceae & Tek Yillık & İstilacı & 8.3 \\
\hline Salvia multicaulis & Lamiaceae & Çok Yıllık & İstilacı & 3.3 \\
\hline \multicolumn{5}{|c|}{ Çatakköprü } \\
\hline Capsella bursa-pastoris & Brassicaceae & Tek Yill1k & İstilacı & 5.1 \\
\hline Hordeum murinum & Poaceae & Tek Yillık & İstilacı & 24.6 \\
\hline Notobasis syriaca & Asteraceae & Tek Yill1k & İstilacı & 10.7 \\
\hline Poa annua & Poaceae & Tek Yillik & İstilacı & 10.7 \\
\hline Polygonum aviculare & Polygonaceae & Tek Yillik & İstilacı & 6.5 \\
\hline Ranunculus arvensis & Ranunculaceae & Tek Yillık & İstilacı & 7.1 \\
\hline Trifolium campestre & Fabaceae & Tek Yillik & İstilacı & 4.2 \\
\hline Trifolium resupinatum & Fabaceae & Tek Yillık & İstilacı & 4.8 \\
\hline Xanthium strumarium & Asteraceae & Tek Yillık & İstilacı & 5.9 \\
\hline Trifolium nigrescens & Fabaceae & Tek Yillık & İstilacı & 15.3 \\
\hline Torilis nodosa & Apiaceae & Çok Y1llık & İstilacı & 5.1 \\
\hline
\end{tabular}

merasında 6 buğdaygil, 1 baklagil, 4 diğer familya türlerinden olmak üzere 11 bitki türü tespit edilmiş, tespit edilen türlerin 9'unun tek yıllık, 2'sinin ise çok yıllık olduğu, etki durumuna göre ise 1 'inin çoğalıcı diğerlerinin ise istilacı tür oldukları tespit edilmiştir. Eskiocak köyü merasında ise 7 buğdaygil, 2 baklagil, 2 diğer familya türlerinden olmak üzere toplam 11 bitki türü saptanmış, tespit edilen türlerin ömürlerine göre 9'unun tek yıllık, diğer 2'sinin ise çok yıllık oldukları, etki durumlarına göre ise 2'sinin çoğalıcı, 9'unun istilacı türlerden oluştukları saptanmıştır. Çatakköprü köyü merasında 2 buğdaygil, 3 baklagil, 6 diğer familya türlerinden olmak üzere toplam 11 bitki türü saptanmıştır. Tespit edilen türlerin ömürlerine göre 10'unun tek yıllık, 1'inin ise çok yıllık, etki durumlarına göre ise tamamının istilacı türlerden oluştukları saptanmıştır (Tablo 2).

Araştırmada incelenen meralarda; azalıcı tür olarak korunga (Onobrychis galegifolia), çoğalıc1 türlerden buzağılık (Stipa arabica), bodur otu (Teucrium polium), köpekdişi ayrığı (Cynodon dactylon), akrep kuyruğu (Coronilla scorpioides), yumrulu arpa (Hordeum bulbosum) ve boncuklu dericikotu (Torilis nodosa) tespit edilmiştir. Bu türler dışında tespit edilen türler ise istilacı türlerdendir.
Azalıcı türlerin kaplama alanına göre botanik kompozisyondaki oranı Alabal köyü merasında \% 3.9 olarak saptanmıştır. Alibey, Darköprü, Dutveren, Eskiocak ve Çatakköprü köyleri meralarında herhangi bir azalıcı türe rastlanmamıştır. Çoğalıcı türlerin kaplama alanına göre botanik kompozisyondaki oranı Alabal köyü merasında \% 5.5, Dutveren köyü merasında \% 5.7 ve Eskiocak köyü merasında ise \% 9.5 olarak saptanmıştır. Alibey, Darköprü ve Çatakköprü köyleri meralarında herhangi bir çoğalıcı türe rastlanmamıştır. İstilacı türlerin kaplama alanına göre botanik kompozisyondaki oranı Alabal köyü merasında \% 90.6, Dutveren köyü merasında \% 94.3, Eskiocak köyü merasında ise \% 90.5 olarak saptanmıştır. Alibey, Darköprü ve Çatakköprü köylerinin meralarında ise \% 100'ünün istilacı türlerden oluştuğu belirlenmiştir (Tablo 3).

Tablo 3. İncelenen meralarda türlerin etki derecelerine göre (azalıcı-çoğalıcı-istilacı) botanik kompozisyondaki oranları (\%)

\begin{tabular}{lccr}
\hline Köy adı & Azalıcı & Çoğalıcı & İstilacı \\
\hline Alabal & 3.9 & 5.5 & 90.6 \\
Alibey & --- & --- & 100.0 \\
Darköprü & --- & --- & 100.0 \\
Dutveren & --- & 5.7 & 94.3 \\
Eskiocak & --- & 9.5 & 90.5 \\
Çatakköprü & --- & --- & 100.0 \\
\hline
\end{tabular}


Araştırmada incelenen meralarda bulunan familya, cins, tür sayıları, bitki ile kaplı alan oranları ve botanik kompozisyondaki familyaların oranları Tablo 4'te görülmektedir. Buna göre incelenen 6 farklı merada toplam 11 bitki familyasından, 35 cinse ait toplam 43 bitki türüne rastlanmıştır. Araştırma sonucunda elde ettiğimiz bulguların, diğer araştırıcıların bulgularıyla (Ayan, 1997; Yavuz, 1999; Aydın ve Uzun, 2000; Şahinoğlu, 2010; Yavuz ve ark., 2011) benzerlik ve farklılıkları bulunmaktadır. Bulgular arasındaki bu farklılıklar; araştırma sahalarının farklı büyüklükte ve farklı iklim özelliklerine sahip olmalarının yanında, farklı vejetasyon ölçüm yöntemlerinin kullanılmasıyla da açıklanabilir.

Araştırmada elde edilen sonuçlara göre vejetasyon etüdü yapılan 6 farklı merada bitki ile kaplı alan oranı \% 46.2-72.0 arasında değişmiş ve bu değişim istatistiksel olarak çok önemli olduğu ortaya çıkmıştır. En yüksek bitki ile kaplı alan oranı (\% 72.0) Çatakköprü köyü merasında, en düşük bitki ile kaplı alan oranı ise (\% 46.2) Darköprü köyü merasında saptanmıștır (Tablo 4). Çatakköprü köyü merasında bitki ile kaplı alan oranının diğer meralara göre daha yüksek olması, bu merada taban suyunun diğer meralardan daha yüksek olması ile açıklanabilir. İncelenen meralar için saptanan bitki ile kaplı alan oranı değerleri, Çınar (2001)'ın Çukurova'nın yüksek kesimlerinde, Şen (2010)'in Kilis'te, İnal ve ark. (2011) ve Çınar ve ark. (2014)'nın Hatay'ın taban meralarında saptadıkları bitki ile kaplılık oranı değerlerinden daha düşük saptanmıştır. Bu duruma neden olarak, söz konusu araştırmalarda kullanılan vejetasyon ölçme yöntemlerinin farklılığın yanında, incelenen meralar arasındaki toprak, iklim ve özellikle yağıș açısından farklılık, otlatma baskısı ve otlayan hayvanların cinsinin farklı olması gösterilebilir.

İncelenen meralarda botanik kompozisyondaki buğdaygiller oranı \% 30.81 ile $\%$ 72.92, baklagillerin oranı \% 16.89 ile \% 48.25, diğer familya bitkileri oranı ise \% 10.19 ile $\% 39.74$ arasında değişim göstermiştir. Tüm parametrelerde istatistiksel olarak fark çok önemli bulunmuştur. Botanik kompozisyondaki en yüksek buğdaygillerin oranı (\% 72.92) ile Eskiocak köyü merasında, en düşük buğdaygil oranı \% 30.81 Çatakköprü köyü merasında tespit edilmiştir (Tablo 4). Ülkemizde doğal meralarda yapılan benzer çalışmalarda botanik kompozisyondaki buğdaygillerin oranını; Erkun (1972), \% 56 ve Gökkuş (1984), \% 57 olarak saptamıştır.

Botanik kompozisyondaki en yüksek baklagillerin oranı \% 48.25 ile Darköprü köyü merasında, en düşük baklagil oranı ise \% 16.89 ile Eskiocak köyü merasında saptanmıştır (Tablo 4). Benzer çalışmalarda botanik kompozisyondaki baklagillerin oranını, Bakır (1963), \% 14.0; Erkun (1972), \% 8.0; Gökkuş (1984), \% 7.8; Uslu (2005), \% 17.8 ve Şen (2010), \% 15.0 olarak saptamıştır.

Botanik kompozisyondaki en yüksek diğer familya oranı \% 39.74 ile Çatakköprü köyü merasında, en düşük diğer familya oranı ise \% 10.19 ile Eskiocak köyü merasında tespit edilmiştir (Tablo 4). Çalışmada tespit edilen botanik kompozisyondaki diğer familya oranı ile ilgili bulgular, Bakır (1963), Erkun (1972), Uslu (2005) ve Çınar ve ark. (2014) tarafindan saptanan değerler ile benzerlik göstermektedir.

\section{Sonuçlar}

Diyarbakır ili meraları karasal iklimin etkisi altındadır. Dolayısıyla bu alanlar sahil kuşağında bulunan meralara göre kuraklikla birlikte otlatma baskısından daha fazla etkilenmekte ve mera vejetasyonları daha fazla zarar görmektedir. Diyarbakır'ın Silvan ilçesi taban mera alanlarında istilac1 ve buğdaygillere ait türlerin ağırlıkta olduğunu söylemek mümkündür. Araştırma sonuçlarına dayanılarak, incelenen meraların vejetasyonlarında genellikle istilacı türlerin baskın olduğu ve bu nedenle de meraların zayıf meralar olduğu, meraların ıslah edilmesi için uygun ıslah yöntemlerinin saptanması amacıyla araştırmalar yürütülmesi gerektiği sonucuna varılmıştır.

Tablo 4. İncelenen köy meralarının bitki örtüsü özellikleri

\begin{tabular}{|c|c|c|c|c|c|c|c|}
\hline \multirow[b]{2}{*}{ Köy adı } & \multirow[b]{2}{*}{$\begin{array}{l}\text { Familya } \\
\text { adeti }\end{array}$} & \multirow[b]{2}{*}{$\begin{array}{l}\text { Cins } \\
\text { adeti }\end{array}$} & \multirow[b]{2}{*}{$\begin{array}{l}\text { Tür } \\
\text { adeti }\end{array}$} & \multirow{2}{*}{$\begin{array}{c}\text { Bitki ile kaplı } \\
\text { alan oranları } \\
(\%)^{*}\end{array}$} & \multicolumn{3}{|c|}{ Botanik kompozisyondaki oranları (\%)* } \\
\hline & & & & & $\begin{array}{l}\text { Buğdaygil } \\
(\%)\end{array}$ & $\begin{array}{l}\text { Baklagil } \\
(\%)\end{array}$ & $\begin{array}{c}\text { Diğer familya } \\
\text { bitkileri (\%) }\end{array}$ \\
\hline$\overline{\text { Alabal }}$ & 3 & 10 & 11 & $61.8 \mathrm{a}-\mathrm{c}$ & $64.19 \mathrm{~b}$ & $17.73 \mathrm{~cd}$ & $18.08 \mathrm{c}$ \\
\hline Alibey & 5 & 8 & 8 & $53.2 \mathrm{~cd}$ & $42.71 \mathrm{~d}$ & $27.03 \mathrm{~b}$ & $30.26 \mathrm{~b}$ \\
\hline Darköprü & 3 & 8 & 8 & $46.2 \mathrm{~d}$ & $32.00 \mathrm{e}$ & $48.25 \mathrm{a}$ & $19.75 \mathrm{c}$ \\
\hline Dutveren & 5 & 11 & 11 & $56.7 \mathrm{~b}-\mathrm{d}$ & $47.12 \mathrm{c}$ & $19.01 \mathrm{c}$ & $34.05 \mathrm{~b}$ \\
\hline Eskiocak & 4 & 8 & 11 & $68.7 \mathrm{ab}$ & $72.92 \mathrm{a}$ & $16.89 \mathrm{~d}$ & $10.19 \mathrm{~d}$ \\
\hline Çatakköprü & 7 & 9 & 11 & $72.0 \mathrm{a}$ & $30.81 \mathrm{e}$ & $29.45 \mathrm{~b}$ & $39.74 \mathrm{a}$ \\
\hline Toplam/Ortalama & 11 & 35 & 43 & 59.8 & 48.29 & 26.39 & 25.35 \\
\hline
\end{tabular}




\section{Teşekkür}

$\mathrm{Bu}$ çalışma Bitkisel Üretim Genel Müdürlüğü (BÜGEM) tarafından desteklenen "Ulusal Mera Kullanım ve Yönetim Projesi” kapsamında yapılmıştır. Desteklerinden dolayı BÜGEM'e, bitki teşhislerini yapan Dicle Üniversitesi Fen Edebiyat Fakültesi Biyoloji Bölümü Öğretim Üyesi Prof. Dr. Alaattin Selçuk ERTEKİN'e teşekkürlerimizi sunarız.

\section{Kaynaklar}

Anonim, 2008. Türkiye'nin Çayır ve Mera Bitkileri. T.C. Tarım ve Köyişleri Bakanlığı, Ankara.

Anonim, 2015. Türkiye İstatistik Kurumu. Temel İstatistikler. http://www.tuik.gov.tr/UstMenu.do? metod=temelist (Erişim tarihi: 02.01.2015).

Avağ, A., Mermer, A., Yıldız, H., Ünal, E., Urla, Ö., Aydoğdu, M., Dedeoğlu, F., Aydoğmuş, O., Torunlar, H., Tuğaç, M.G., Ünal, S., Mutlu, Z., Özaydın, K.A., Özgöz, M.M., Aksakal, E., Kara, A., Uzun, M., Çakal, S.., Yıldırım, T., Aksoyak, S.., Tezel, M., Aygün, C., Kara, İ., Erdoğdu, İ., Sever, L., Atalay, A., Yavuz, T., Avcı, M., Çınar, S., İnal, İ., Yücel, C., Cebel, H., Keçeci, M., Başkan, O., Depel, G., Palta, Ç., Çarkacı, A., Karadavut, U. Şimşek, U., Sürmen, M., Odabaşı, G., Gül, D., Koç, A., Erkovan, H.İ., Güllapoğlu, K., Kendir, H., Şahin, N., 2012. TUBİTAK 106G017 nolu Ulusal Mera Kullanımı ve Yönetim Projesi Sonuç Raporu, Ankara.

Ayan, İ., 1997. Samsun yöresi engebeli meralarında değişik 1slah yöntemlerinin etkileri üzerinde bir araştırma. Doktora tezi, Ondokuz Mayıs Üniversitesi Fen Bilimleri Enstitüsü, Samsun.

Aydın, İ., Uzun, F., 2000. Ladik ilçesi Salur köyü merasında farklı 1slah metotlarının ot verimi ve botanik kompozisyon üzerine etkileri. Turk J Agric Forestry, 24: 301-307.

Aydın, İ., Uzun, F., 2002. Çayır Mera Amenajmanı ve Islahi. Ondokuzmayıs Üniversitesi Ziraat Fakültesi Ders Kitab1, No: 9, Samsun.

Bakır, Ö., 1963. ODTÜ arazisinde bir mera etüdü. Ankara Üniversitesi Ziraat Fakültesi Yayınları, No: 382, Ankara.

Çınar, S., 2001. Adana ili Tufanbeyli ilçesi Hanyeri köyü merasında verim ve botanik kompozisyonun saptanması üzerine bir araştırma. Yüksek lisans tezi, Çukurova Üniversitesi Fen Bilimleri Enstitüsü, Adana.

Çınar, S., Hatipoğlu, R., Avcı, M., İnal, İ., Yücel, C., Avağ, A., 2014. Hatay ili Kurıkhan ilçesi taban meraların vejetasyon yapısı üzerine bir araştırma. Gaziosmanpaşa Üniversitesi Ziraat Fakültesi Dergisi, 31(2): 52-60.

Davis, P.H., 1969. Flora of Turkey and the Eastaege an Islands. University of Edinburgh Press, Volume 13, Edinburgh.
De Vries, D.M., De Boer, T.A., Dirver, J.P.P., 1951 Evaluation of grassland by botanical research in the Netherlands. Proceedings of the United Nationals Scientific Conference on the Conservation and Utilization of Resources, 6, 522-524.

Demiri, M., 1983. Flora Ekskursioniste e Shqiperise. Shtepia Botuese e Librit Shkollor, Tirana.

Edgecombe, W., 1964. Weeds of Lebanon. Faculty of Agriculture Sciences American University of Beirut, Publication No: 24, Lebanon.

Erkun, V., 1971. Hakkari ve Van illerinde mera araştırmaları. Tarım Bakanlığı Ziraat İşleri Genel Müdürlüğü Yayınları No:13, Ankara.

Erkun, V., 1972. Bala ilçesi meraları üzerinde araştırmalar. Tarım Bakanlığı Hayvancılığı Geliştirme Genel Müdürlüğü Yayınları, Ankara.

Garms, H., Eigener, W., Melderis, A., Pope, T., Durrell, G., 1968. The Natural History of Europe. Paol Hamilyn Limited, London.

Gökkuş, A., 1984. Değişik 1slah yöntemleri uygulanan Erzurum tabii meralarının kuru ot ve ham protein verimleri ile botanik kompozisyonları üzerinde araştırmalar. Doktora tezi, Atatürk Üniversitesi Ziraat Fakültesi, Erzurum.

Gökkuş, A., 1991. Doğu ve Güney Doğu Anadolu Bölgeleri çayır mera ve yem bitkileri ve hayvancılığı geliştirme projesi eğitim semineri. 20 22 Şubat, Erzurum.

Gökkuş, A., Koç, A., Çomaklı, B., 2000. Çayır-Mera Uygulama Kılavuzu. Atatürk Üniversitesi Ziraat Fakültesi Yayınları No: 142, Erzurum.

Huxley, A., Taylor, W., 1977. Flowers of Greece and the Aeg Eanchatto and Windusltd. Printed Great Britain by Richard Clay Ltd Bunges, Suffolk.

İnal, İ., Avcı, M., Çınar, S., Yücel, C., Hatipoğlu, R., 2011. Çukurova Bölgesi sahil meralarının vejetasyon yapısı üzerine bir araștırma. IX. Tarla Bitkileri Kongresi Sunulu Bildiri, 3. Cilt, 12-15 Eylül, Bursa, s. 1664-1667.

Koç, A., Çakal, Ş., 2004. Comparison of somerange landcanopy coverage methods. Int. Soil Cong. On Natural Resource Manage. For Sust. Develp. June 7-10, Erzurum-Turkey, D7, 41-45.

Özmen, T., 1977. Konya ili meralarının bitki örtüsü üzerinde araştırmalar. Doktora tezi, Ankara Üniversitesi Fen Bilimleri Enstitüsü, Ankara.

Öztan, Y., Okatan, A., 1985. Çayır Mera Baklagil ve Buğdaygil Yem Bitkilerinin Tanıtım Kılavuzu. Cilt II, Karadeniz Teknik Üniversitesi Orman Fakültesi, Karadeniz Üniversitesi Basımevi Genel Yayın No: 95, Fakülte Yayın No: 8, Trabzon.

Polunin, O., Huxley, A., 1974. Flowers of the Mediterranean Chatto and Windus, London.

Şahinoğlu, O., 2010. Bafra ilçesi koşu köyü merasında uygulanan farklı sslah yöntemlerinin meranın ot verimi, yem kalitesi ve botanik kompozisyonu üzerine etkileri. Doktora tezi, Ondokuz Mayıs Üniversitesi Fen Bilimleri Enstitüsü, Tarla Bitkileri Anabilim Dalı, Samsun. 
Sen, C., 2010. Kilis ili bazı köylerindeki meralarda vejetasyon yapısı üzerine bir araştırma. Yüksek lisans tezi, Çukurova Üniversitesi Fen Bilimleri Enstitüsü, Adana.

Tükel, T., 1981. Ulukışla'da korunan tipik bir step dağ merası ile eş orta malı meraların bitki örtüsü ve verim güçlerinin saptanması üzerine araștırmalar. Doçentlik tezi, Çukurova Üniversitesi Ziraat Fakültesi, Adana.

Uslu, M.S., 2005. Kahramanmaraş ili Türkoğlu ilçesi Araplar Köyü Yeni Yapan merasında botanik kompozisyonun tespiti ve farklı gübre uygulamalarının meranın verim ve botanik kompozisyonuna etkileri üzerinde araștırmalar. Doktora tezi, Çukurova Üniversitesi Fen Bilimleri Enstitüsü, Adana.

Weymer, H., 1981. Lernt Pflanze Kennen Ferdinand Enke Verflog, Stuttgart.
Yavuz, T., 1999. Tokat ili Taşlıçiftlik köyü doğal merasının gübreleme ve dinlendirme yöntemi ile ıslah olanakları üzerine bir araştırma. Yüksek lisans tezi, Gaziosmanpaşa Üniversitesi Fen Bilimleri Enstitüsü, Tokat.

Yavuz, T., Sürmen, M., Töngel, M.Ö., Avağ, A., Özaydın, A.K., Yıldı, H., 2011. Samsun ili meralarının vejetasyon özellikleri. Türkiye 9. Tarla bitkileri Kongresi, Çayır Mera Yem Bitkileri, Cilt III, 12-15 Eylül, Bursa, s. 1773-1778.

Yılmaz, T., 1977. Konya ili sorun alanlarında oluşan meraların bitki örtüsü üzerine araştırmalar. Tarım Bakanlığı Toprak-Su Genel Müdürlüğü, Konya Toprak Su Bölge Araştırma Enstitüsü Yayınları, Genel Yayın No: 46, Konya.

Yurtsever, N., 1984. Deneysel İstatistik Metotları. Köy Hizmetleri Genel Müdürlüğ̈̈ Yayınları, Genel Yayın No: 121, Ankara. 